\title{
REDEFINING TRANSFORMATION DRIVERS IN SMES TOWARD BUSINESS PERFORMANCE WITH COVID-19 SITUATION IN INDONESIA
}

\author{
Ligasyah Arnanda Primadana ${ }^{1^{*}}$ \\ Muhamad Abdilah Ramdani² \\ Shifa Hustima Sahara ${ }^{3}$ \\ Atik Aprianingsih 4 \\ 1,2,3,4 Institut Teknologi Bandung
}

*Corresponding Author: ligasyah_arnanda@sbm-itb.ac.id

\begin{abstract}
The purpose of this study is to understand transformation drives using past research as the basis of argument on every variable with business performance as the measurement standard. The research using deep searching of journal databases, the output is conducting a conceptual framework. The transformation drivers in our conceptual framework have six factors namely organization, technology, consumer behavior, financial, external support, and network with the measure of success of that transformation drives using business performance. The result is that the past research supports all the purposes of points in the variable that can positively contribute to business performance.
\end{abstract}

Keywords: Business Performance, Conceptual Paper, Covid-19, Indonesia, SMEs, Transformation Drivers

\section{INTRODUCTION}

The infection by severe acute respiratory syndrome coronavirus-2 (SARS-CoV-2), commonly known as coronavirus disease (Covid-19), was declared by the world health organization (WHO) as a global pandemic in Mid-March 2020. The Indonesian government issued the large-scale social restriction policy in response Covid-19 outbreak by minimizing people's outside activities, prohibiting social gatherings, and requiring staying at home (Oktora et al., 2020). The policy of social restriction impacts people's physical and psychological effects and economic consequences, particularly on micro-, small-, and medium-sized enterprises (MSMEs, Pratama et al., 2021; Rodrigues et al., 2021).

In Indonesia, SMEs are the economic backbones that acquired $99 \%$ of business units, providing $97 \%$ of job opportunities and contributing 60\% to GDP (Depkop, 2018). 
According to Indonesia Statistics Bureau (BPS, 2020), 84\% of SMEs in Indonesia experience revenue decrease because of the change in market demand and supply impacted by the Covid-19 pandemic. The condition may be related to the impact of Covid19 , which has resulted in consumer behavior change, knowledge gap in managerial and technology caused digitalization, operational hours decrease, and delivery delay in the supply chain (García-villagrán et al., 2020; Klein \& Todesco, 2021; Pratama et al., 2021). Besides, SME needs to enrich their management, strategic planning, and innovation knowledge to formulate their new business model to adapt to new market demand to survive (Caballero-Morales, 2021).

Transformation in SMEs is the key answer to respond to the crisis due to the Covid19 pandemic. The transformation aims to make businesses stronger (rather than larger) by developing their quality by improving resource allocation efficiency (Wang et al., 2021). Gregurec et al. (2021) has conducted content analysis on literature to identify driver factors in SMEs transformation and found five drivers as the most occurrence are related to technology, organization, financial, consumer, and general social. Those factors identified by Gregurec et al. (2021) related to the finding by Nurunnabi (2020) on a recovery plan and resilience in SMEs during pandemic with the recommendation transform are an organization (renewal strategy and considering vision and mission as a new way for managing risk and uncertainty), financial (top priority), and government (support and stimulus). Also, the drivers related to the study from Winarsih et al. (2021) regarding transformation that taken to result in sustainability in SMEs such as technology (digital marketing utilization to promote a product), organization (maintain cash flow and monitoring business transaction), financial (re-budgeting), and supply chain (inventory management). Complemented prior studies, research by Pratama et al. (2021) discuss strategic development in SMEs. The paper presented a literature review on how Indonesian SMEs respond to business survival and recovery during the Covid-19 outbreak. The proposed strategic recommendations include digital transformation, financial management, supply chain, network relationship, government policy, orientation, and information.

However, as the main literature in transformation drivers, a study by Gregurec et al. (2021) has not identified the change of distribution on supply chain, network relationship, and government policy, which was proposed by Fath et al. (2021); Garcíavillagrán et al. (2020); Nurunnabi (2020); Pratama et al. (2021); Winarsih et al. (2021) as the driver factors SMEs should focus in coping the pandemic crisis. In addition, apart from driver factors in SMEs' transformation which they recommend important for business continuity, these studies have not determined whether these driving factors affect business performance economically and non-economically. Therefore, considering the practical and theoretical contribution, it is a gap that we are trying to fill in by conducting a literature review on driver factors of SMEs transformation due to Covid-19 and its relation to business performance in one of the world's largest economies, Indonesia. 
In answering the research objective, the present study conducts a literature review by focusing on identifying the paper in the context of transformation in SMEs affected by Covid-19 and the contribution to economic and non-economic performance. The articles published in the Scopus, ScienceDirect, Google Scholar, and Emerald databases were selected to accomplish analysis and to provide an overview comprehensively. The papers will integrate to be conceptual models as the result of the discussion. As a reminder of the structure of this study, the following section discussed literature regarding small and medium enterprises, business transformation, and business performance. The detail of the method of this study is disclosed in the third section. The propositions related to transformation drivers on startup business performance for sustainability in survival in the pandemic explored in the fourth section. Next, we presented a theoretical model as the result of theoretical analysis. The last section summarizes some highlights of this study and future research recommendations.

\section{LITERATURE REVIEW \\ SMEs in the Covid-19 era}

Small and medium enterprises play a crucial role in enhancing the community's social welfare and Indonesia's economic growth. SMEs consist of 99.99 percent of the total business actors in Indonesia, or 56.54 million units (Hendayana et al., 2019). According to Indonesia Statistics Bureau (BPS, 2020), 84\% of SMEs in Indonesia experience revenue decrease because of the change in market demand and supply impacted by the Covid-19 pandemic. In Indonesia, SMEs defined in Act Number 20 of 2008, i.e., the company classified as an SME is a small company owned and managed by someone or owned by a small group of people with a certain amount of wealth and income (Hennig-thurau et al., 2010). Meanwhile, covid-19 impact on the Indonesian economy has been strongly significant since the government announced that 2 (two) Indonesian citizens have been infected by the Coronavirus on March 2 of 2020. The exchange rate of Indonesia Rupiah (IDR) to United States Dollar (USD) was greatly affected by this announcement, where IDR has depreciated to a level of IDR 16,000 per USD. This exchange rate is the weakest in the last five years, from 2015 to 2020 (HumasUNS, 2020). Sri Mulyani, the Minister of Financial Affairs for the Republic of Indonesia, predicted that the economic sector would dramatically degenerate because the covid-19 pandemic has pushed down economic growth to come near zero, precisely at $0.3 \%$, or even to attain a negative level, precisely at minus 2.6\% (Abrar, 2020). Economic degradation due to the covid-19 pandemic had a significant impact on the business world, including Small and Medium Enterprises (SMEs). Based on a survey, ninety-six percent $(96 \%)$ SMEs admitted that their business operations suffered due to the covid-19 pandemic. Seventy-five percent $(75 \%)$ of SMEs reported that their sales are declining significantly (Hermansah, 2020). 


\section{Business Transformation}

Coronavirus pandemic has affected several challenges for businesses in both developed and developing economies. Businesses are still suffering such crises and disruptions and expect to meet new challenges and recessions during unexpected pandemic conditions (Salamzadeh \& Dana, 2020). According to Salamzadeh \& Dana (2020), in the context of Asia, the Covid-19 pandemic has driven several challenges for entrepreneurs in emerging economies. The data collected through focus groups and interviews with co-founders regarding the main challenge in their business during the coronavirus pandemic. Six important challenges faced by businesses were covid-19 such as the financial, human resources, marketing, management crisis, and further challenges in the business model. In SMEs, Klein \& Todesco (2021) argue the impact of Covid-19 resulted in a change in consumer demand, organization shakes (management and technology knowledge gaps, mass layoffs, decrease in sales, temporary and permanent closures), and scarcity of financial resources. Another view on business environment change in SME discussed by García-Villagrán (2021) regarding survival strategy in the supply chain that SME should focus on since the availability of materials and goods, delivery time, and inventory management is changed. Challenges faced by SMEs in developing countries can lead to business success or failure (Pratama et al., 2021). The negative impact of business changes affected by the pandemic can be avoided through strategic development design. In other words, SMEs can focus on understanding the key challenges and seek to identify the transformation drivers that they must determine to sustain their business in this crisis era.

Business transformation realizes companies' core business changes and responds to these changes by allocating resources (Wang et al., 2021). Hutabarat et al. (2021) define business transformation as a series of change processes required by companies to respond to new business challenges to better their position than competitors. There are five stages in business transformation proposed by Hutabarat et al. (2021). First, set the company direction, objective, and position to make themselves more competitive by developing through vision and corporate strategic development. The second and third steps are to improve company/organizational capability and develop human resources to make fundamental changes in the organization system. Fourth is strengthening the company's culture to directed desired goals. The last is the process of a company achieving goals and value creation.

Many scholars state that transformation in businesses is an appropriate long-term strategy for SMEs to deal with the crisis era, such as the covid-19 pandemic. According to Grague et al. (2021), in SME literature, transformation does not explicitly state, and through the content analysis, there are five transformation drivers in SME: technology, consumer, financial, organization, and general social. Some studies also discuss transformation drivers in business during Covid-19 as the potential strategic process to cope with the crisis era. For example, transformation in an organization (Muñoz-pascual, 
2021; Nurunnabi, 2020); Technology (Jiménez-zarco et al., 2021; Nuseir \& Aljumah, 2020; Winarsih et al., 2021); Consumer behavior (Harahap et al., 2020); Financial (Klein \& Todesco, 2021; Moretto \& Caniato, 2021), External Support (Falahat et al., 2021), Network relationship (Adam et al., 2020; Arsik et al., 2018; Guan et al., 2020; Ivanov, 2020; Ivanov and Dolgui 2020; Guan et al., 2020; Meqdadi et al., 2020; Saputra et al., 2021; Siu, 2016; Sodhi, 2016; Utomo et al., 2020), and as the benchmark business performance (Rachmawati \& Widowati, 2021).

\section{Business Performance}

In past research, they are usually evaluating the value of the SME. The value of an SME is the evaluation of the SME performance. Usually, this data will be important for getting investors to our company. There are some indicators for business performance for this paper. There will be two categories there are financial and non-financial.

\section{Financial indicator}

Even SME is relatively small in terms of big money, but the health of financial factors is really important to evaluate. How SME owners handle their budget to make their SME is one of the main factors to survive. In past research, SME funding policies will provide the direction of SME to handle the funds, source of funds, and ability to finance for increasing business value (Rachmawati \& Widowati, 2021). In addition to the research, the entrepreneurship capability and internal financial dimension positively affected SME (Rachmawati \& Widowati, 2021). Adopt from past research using measurement of their performance using several indicators, return on assets (RoA), average annual occupancy rate, net profit after tax, and return on investment (Rol) (Rosli \& Sidek, 2013). These factors are usually calculated using accounting indicators by the standard of the firms. Other possibilities of measurement that can be used are profitability, productivity, growth, stakeholder satisfaction, market share, and competitive position (Rosli \& Sidek, 2013).

\section{Non-Financial indicator}

The indicator to measure business performance besides financial is necessary to know the real progression of the business performance. The combination of financial and non-financial will be whole picture performance. The non-financial performance based on past research talks about internal and external environments (Rosli \& Sidek, 2013). Entrepreneurial orientation is one example of business performance. The research tells that entrepreneurial orientation positively contributes to business performance by suggesting various contexts in the business itself (Vaitoonkiat \& Charoensukmongkol, 2020). Another non-financial factor is entrepreneurship capability; the role of this variable is about innovation and can create an improvement of the firm's performance (Rachmawati \& Widowati, 2021). From another research, organizational culture can influence the business's performance with innovation triggered (Prima Lita et al., 2020). 
The explanation above about financial and non-financial factors shows how business performance can be an accurate measurement to know how the business works. This measurement will be the basis of our researchers wanting to know how the transformation drivers can influence the business performance using the possible past research where the transformation drives can influence a financial or non-financial factor or influence both simultaneously.

\section{RESEARCH METHOD}

Research on the impact of the COVID-19 outbreak on SMEs transformation could be a modern thought. A few past research inspected the variables that progress and how utilized a few strategies for getting better in the business performance. This research uses deep searching into the journal database as a method, and also, the related journal will be analyzed to support the argument about the variable.

For particular purposes, we choose both quantitative and qualitative methods of the result of the journal for our basic argument. Paper followed by utilizing a few keywords such as "COVID-19", "Small and Medium Enterprise", "transformation driver", "business performance", "external support", "human resource", "human capital", "leadership", "consumer behavior", "financial", "technology", "digital", "network relationship", "customer relationship", "collaboration", and "supply chain relationship". The publication will be analyzed for 2020 to 2021 on Emerald, Google Scholar, ScienceDirect, and Scopus.

\section{DATA ANALYSIS AND DISCUSSIONS}

The existence of the COVID-19 pandemic has affected the performance of various business sectors such as small and medium enterprises, which are considered a supporting factor for Indonesia's economic development and the long-term competitiveness of the Indonesian stock market. SMEs are particularly vulnerable since they must cope with layoffs, operations closures, cash flow issues, conservation, and a weakening of their capacity for future growth (Wahyudi, 2014). It is necessary to follow up on future strategies so that SMEs can survive. This literature study provides input related to the transformation of drivers that can improve business performance, especially in changing financial and non-financial organizations, to maintain and attract new jobs.

\section{Organization}

The role of human resources $(\mathrm{HR})$ is important for organizations since human capital is one of the essential resources in creating a competitive business advantage (Baryshnikova et al., 2021). According to Sukartini et al. (2018), organizations can maintain their competitiveness in the environment by considering the human resource who has the knowledge, capability, competitiveness and qualification, and the ability to perform various tasks in the job. When an organization can maintain and focus on human 
resources, continuous competitive advantage can be achieved, particularly for companies in the middle of the dynamic and competitive environment that demand human resources skills to access new markets and technology (Nohong et al., 2021). Barney \& Wright (1998) have developed the resource-based view (RBV) notion in explaining the competitive business advantage that links business resources and performance. This view can be defined that human capital resources in an organization are related to organization performance. Prior research from Nohong et al. (2021) in analyzing human resource investment and enterprise performance in Indonesia has been conducted with the result of relation both variables significantly influence. The paper states that the better SME investment in human resources, the better their business performance can be achieved. The outcome of business performance in the paper is to boost financial increase and non-financial such as businesses' capabilities in managing obligations. Like other research on Indonesia SME, the quality of human resources is directly affecting business performance (Zuraida et al., 2017). This statement means the high quality of employees will directly impact their high innovation to the business, and this innovation is related to the increase of business performance. This paper also found that the quality of employees and SME investment in human resources have positively impacted business growth. These findings are also supported by prior research and conclude that the human resource management system positively affects business performance (Huang, 2014; Pham, 2020).

The second indicator in defining the organizational aspect is the role of strategic leadership. In the context of SME, the success factors of SME can be defined by the leader's commitment and capability. This leader's commitment and capability can build a company's capacity to change and continue the business based on a strategic workflow to sustain and compete in the dynamic environment of a business ecosystem (Mui et al., 2018). Furthermore, leaders' capability is encouraged to formulate, implement, and influence the whole organizational actors to collaborate in creating competitive advantage in the external environment turbulence. Strategic leadership is defined as the responsibility of organizational leaders in formulating, implementing, and performing strategic continuous and the capability to utilize the change adjustment according to the organization resources, management team, and environment characteristics (Hosmer, 1986). A leader with innovation capability has shown significantly influenced organizational performance (Mui et al., 2018). Related to that finding, Jing et al. (2020) found that leadership with the vision and organic, communicative, easy to share, and ensuring a positive climate in the organization is related to financial business performance. Those two findings depict that leaders with strong innovation and vision capability can be defined as the factors in identifying business performance. The leaders who can transform themselves in work are related to their contribution to enhancing SMEs' operations. 


\section{Organization in Covid-19 context}

SME has fewer technical capabilities and financial savings, small (even nonexisting) research, innovation and development (R\&D), and difficulty recruiting skilled employees. Although these difficulties, SME can compensate by relying on their strength, consider the development of innovation, receptive to change, adaptable, and less procedure and bureaucratic (Ibarra et al., 2020). Covid-19 hits many sectors in economics, and SME is found as the organization most seriously affected by pandemics (Rodrigues et al., 2021). Despite uncertain conditions present in the business environment, SME can continue their business activities by adapting to new business demands caused by disrupted conditions in the pandemic. The study from Rodrigues et al. (2021) explains that leaders take a role in reconsidering business activities by adopting management efficiency utilizing the company's existing tangible and intangible resources. Leaders also consider risk management as a long-term vision and mission in conditions of uncertainty for SMEs Affected by the pandemic (Nurunnabi, 2020). Another study by Amuda (2020) discusses SME leaders' role in business expansion and explores business opportunity as the defensive strategy during coronavirus pandemics.

Strategic improvement, defensive, and recovery are related to the need for SME to change their organization to survive their business sustainability in the crisis condition. These statement supported by several prior studies regarding the organizational change that produce by human resource capability and strategic leadership impact on business performance (Jing et al., 2020; Paudel, 2018; Purwati et al., 2021; Strukan et al., 2017; Sukartini et al., 2018; Zuraida et al., 2017). The finding by Muñoz-Pascual et al. (2021) also explains that suitable HR with knowledge, motivation, and relationship with stakeholders is related to employee's creativity. This creative outcome directly influences product performance sustainability and economic benefit during pandemics. Besides, according to Sanusi et al. (2020), organizations with leaders who transform their characteristics in lead business processes during pandemics influence SME performance. The leader's characteristics are those who have a vision, can motivate the employee, and solve the problem properly during the covid-19 pandemic. The finding also reveals the leadership style such as democratic, autocratic, and charismatic found influencing positive outcomes for business during the pandemic. Therefore, SMEs need to overcome this crisis era by considering business sustainability and improving performance by transforming leadership characteristics and developing strategic leadership. In addition, the empowerment of human resources to improve skills and capacities is also needed.

Proposition 1a: Organizational change in SMEs through human resources and capabilities positively improve business performance in the Covid-19 era.

Proposition 1b: Strategic leadership in organizational change positively improves business performance in the Covid-19 era. 


\section{Technology}

Technology has dramatically changed the internal and external business environments. The emergence of technology influences traditional business activities approaches and motivates businesses to rethink strategic innovation to remain competitive in the digital era (Nuseir \& Aljumah, 2020). Soto-Acosta (2020) states that technology use in organizations drives significant change in the business model; this related to the use of new technology in response to the change of environment has influenced business transformation model and strategy. The utilization of technology has been beneficial for many organizations, especially small and medium businesses. Wardaya et al. (2019) explained that when SMEs can provide assembly organizational resources to deal with environmental changes by utilizing technology, organizational performance results are achieved from these efforts. Nuseir \& Aljumah (2020) also support this argument and argue that the adoption of technology by SMEs in gaining consumers is related to external competitive pressures on how competitors approach the market efficiently and effectively. The adoption of technology is similar to Astuti et al.'s (2020) research on the determinants of organizations using technology for innovation adoption. They reveal the strategic and persuasive factors of innovation, company characteristics, and organizational readiness as determinants of innovation adoption through technology.

In business processes, technology can solve sales and supply chain problems when businesses face shift conditions (Winarsih et al., 2021). Digitalization in the supply chain can connect businesses with their raw materials and consumers. The SME that adopt innovation using technology has become innovative businesses and enhances their performance. Another study by Kuntonbutr et al. (2020) regarding organizational support in technology adoption on business performance revealed significant influence among variables. Related to technology utilization, they argue technology can encourage knowledge management, sustain the business operation, connect with stakeholders, reduce supply chain cost, and foster competition. Based on evidence from previous research, technology is the driver of transformation in business, and the utilization of its technology is related to business performance.

\section{Technology in Covid-19 context}

Due to territorial restriction, policy on social distance, and the new change of daily business activities caused by the coronavirus pandemic have influenced the business process. For example, small restaurant businesses in China fight for their survival because of the uncertainty of consumer demand, high costs, and negative cash flow (Vig \& Agarwal, 2021). With the change of business environment and consumer consumption pattern, this business's revival depends on owner evaluation of the overall business model and approach to new strategic technology integration in business operation and digital intervention. Another example in Spain SMEs, transformation in business by 
utilizing social media marketing generates a positive impact on financial performance (Jiménez-Zarco et al., 2021). Social media marketing helps small businesses retain loyal customers, keep sales percentage, and establish the first contact with new consumers from different geographical areas.

Research by Patma et al. (2020) revealed that SME adoption on the internet and e-business technology during a pandemic is determined by perceived benefit and external pressure. This finding means that the COVID-19 pandemic hit SMEs with a decline in consumer demand and income, the pressure pushing them to adopt new technologies in approaching consumers remotely, which is considered beneficial for the sustainability of their business. Viswanathan \& Telukdarie (2021) indicate that SMEs ' digitalization brings cost reduction, productivity, and scope innovation to the new business model, impacting SME sustainability and performance. Digital technology adoption has delivered opportunities for SME to survive these times of covid-19 challenge. Supporting this statement, Guo et al. (2020) argue that SMEs' efforts on digitalization manifested by their degree of change and adoption of digital technologies, which can help them cope with the covid-19 crisis. Furthermore, the strategic implementation of digitalization in business improves business performance (Guo et al., 2020).

Proposition 2: Technology change positively improves business performance in the Covid-19 era.

\section{Consumer behavior}

Consumer behavior is currently getting much attention because of its important role in anticipating business performance and achieving its sustainable competitive advantage. Consumer purchasing decisions in the SME market are an important consideration for SMEs in Indonesia. It will impact the SME market, which provides various products to meet consumers' needs and desires. The SME market must be responsive in managing its business so that consumers remain interested in shopping at their stores. Consumers tend to have many choices in shopping at the SME market to meet their needs (Harahap et al., 2020). The purchase decision-making process is where the buyer decides the choice of products or services to be purchased. Khan and Lodhi (2016) found that consumers always try to choose products that match most consumers' images. The preferred style and the attractiveness of celebrities' fashion influence their purchasing decisions and increase the effectiveness of celebrity-endorsed advertisements. In addition, consumer behavior in purchasing decisions in the Indonesian SME market is influenced by several factors: location, price, product completeness, product quality, service quality, other factors such as; security and promotion. It means that all of these factors are important considerations for consumers to buy products in the SME market, which can reference the SME market to implement strategies to continue to shop (Gonda et al., 2020). Currently, loyal customers have become an element of capital and one of the key success factors in business performance. Therefore, accurate 
knowledge and compliance with consumer needs and expectations are essential for a successful business.

\section{Consumer behavior in Covid-19 context}

The lockdowns brought about by the COVID-19 have caused people to have to cope with changes in their activities. Challenges range from self-isolation to hoarding fundamental commodities. Many people flock to buy food, medicine, and vitamins, which can support their health to survive. The process used by consumers in choosing products is an indispensable element in the strategy of each entity (Rajagopal, 2020). In normal situations, the consumer's decision to choose a product or not is often associated with its intrinsic and extrinsic characteristics (Asioli et al., 2017). In the context of the COVID-19 pandemic, there has been a change in perspective on the use of some products, emphasizing providing food and reducing the luxury goods and services sector. In this context of economic, social, and political instability, consumers experience systematic pressures perceived as losing control over their environment (Botti and McGill, 2011). Stress determines him either to save money to gather resources that will offer comfort or to manifest impulsive behavior in buying products that he considers necessary (Durante and Laran, 2016).

Another condition when uncertainty surrounding work looms, individuals have limited their income-expenditure, which can be spent on areas such as takeaways while simultaneously cooking at home with limited food ingredients due to supply chain shortages (Zutshi et al., 2021). Worse, most individuals begin to act in what is considered to be uncivilized behavior (e.g., stashing or looting) due to declining finances and job loss (Donthu and Gustafsson, 2020). In addition to storage or panic buying events (Hall et al., 2020; Jabbour et al., 2020), the presence of health protocols related to social distancing and lockdowns leads to an increased danger of developing residential outrages (physical, arousal, and sexual harassment) (Kumar et al., 2020). Therefore, companies must also adapt their strategies to consumer behavior and identify new ways to reach customers. Based on a survey conducted by Stanciu et al. (2020) among consumers in 100 countries, there is a common evolution for all markets affected by the pandemic. Companies need to understand and adapt to these changes so that they can better plan future actions. Companies should understand consumer needs and fears to adjust the distribution chain and product offerings to remove new consumption barriers from the consumer's front and make it easier to sell products. In addition, Gonda et al. (2020) suggest that in managing their target consumer groups, SMEs should strive to increase customer loyalty, increase purchase satisfaction, and improve marketing strategies by getting more people to become direct advertisers or so-called brand ambassadors who talk about the brand and brand products to friends (friends in their environment). This analysis intends to support SMEs business owners in understanding customer behavior, showing which business areas focus on increasing customer loyalty or purchase satisfaction to impact business performance positively. 
Preposition 3: Consumer behavior change positively improve business performance in the Covid-19 era

\section{Financial}

According to Rachmawati \& Widowati (2021), finances were the most influential factor in SMEs' difficulties, followed by raw material and marketing factors. They also found that entrepreneurship capability and their internal financial dimension (own capital) improve business performance. Supported that finding, Wahyono \& Hutahayan (2021) explain that entrepreneurs who know financial management will make the right decision in their organization. The good financial literacy of entrepreneurs in SME has also influenced their knowledge competency, creating a new idea and innovation, and directly impacting business performance. The factor of SMEs actor on financial literacy and capability that found a positive impact on business performance (financial or non-financial performance) have been discussed by several findings of prior research in the context of Indonesian SMEs (see. Buchdadi et al., 2020; Hendrawaty et al., 2020; Hindasah \& Nuryakin, 2020; Rita \& Huruta, 2020). Therefore, in Indonesia, SMEs' capacity and literacy on financial matters are determinant factors for business sustainability. Financial knowledge can improve business execution effectively and efficiently and create an innovative response to market demand which all this process created positive benefits for the business.

\section{Financial in Covid-19 context}

Pratama et al. (2021) conduct a review on the Covid-19 effect from the perspective of SMEs' owners and provide strategy suggestions to deal with the pandemic outbreak. Their strategic development pointed to financial management as one strategy that SME should focus on to help their survival in the crisis era. This finding may be related to Sun et al. (2021) that states the coronavirus pandemic suffered financially for SME. A decline in market demand caused this financial problem, restricted logistic and crowd flow, and postponed work resumption and account receivables. A study from Klein \& Todesco (2021) in investigating the financial health of SME affected by Coronavirus shows that pandemic has impacted financial threat which results in SME permanently and temporarily closing, dominantly loses monthly sales and less financial option. The role of digitalization to cope SME with the current situation and future uncertainties after a pandemic is proposed by them in response to the new reality and new consumer demand. Therefore, achieving business benefits by adopting new business technology requires SME owners to change their financial allocation in the business. Financial change is more allocated to the innovation adoption by utilizing technology tools in the organization and business process-driven transformation in SME. It is related to SMEs' sustainability during a pandemic by Winarsih et al. (2021); transformation in finances is essential for businesses to maintain their performance by re-budgeting allocation to priorities items and to adjust the budget conditions. Managing income and expenditure budget items is related to businesses' control on profit margin and anticipating the risk. 
Preposition 4: Financially change positively improve business performance in the Covid19 era

\section{External Support}

External support is necessary for the survival ability of SME. The support can be financial or non-financial. The financial, of course, is talking about resources and economics. However, for the non-financial, it can be supported by government regulation or knowledge sharing. Government support impacts SME multiple strategic orientations can boost the speed and scope of SME in their business capability (Falahat et al., 2021). Nevertheless, knowledge sharing from collaboration can help SME learn and deploy such strategies as acquisition, assimilation, and application (Benhayoun et al., 2021). To attain the knowledge, we suggest external support should be considered in the transformation drive. In our purpose, the external support can be from the environment and or government. There are so many movements from the environment to change SME and trigger them to transform and do innovation in the current condition. Recently, research showed the significance and moderating role of external support to SME to survive in the pandemic situation (Adam \& Alarifi, 2021). From the explanation, we state external support as one variable in transformation drivers.

\section{External Support in Covid-19 Context}

Dramatical change happens because, in the current covid-19 pandemic situation, the SMEs find it quite hard to survive financially or non-financial. As mentioned above, there are certain conditions where external support becomes necessary for SME survival. The impact of external support can strengthen and give more positive in SME (Adam \& Alarifi, 2021). For example, new small businesses such as street food in lockdown situations cannot do normal activities; therefore, they need to keep selling traditional ways. However, external support such as donations using kitabisa.com to make some SME still can survive. Lockdown condition is policy and government, so government support is necessary for making SME such as street food still survive. An example of government support is a statement from one of a minister in Indonesia to create a program to support SME to survive using "Pemulihan Ekonomi Nasional" (PEN) (Media Indonesia).

Proposition 5a: External Support from Environment positively improve business performance in the Covid-19 era.

Preposition 5b: External Support from the Government plays a certain role in improving positive business performance in the Covid-19 era.

\section{Network}

Network relationships become a new challenge when SMEs start developing relationships with other companies because of the need to achieve social impact and 
business performance. The network creates a potential tension between social and commercial logic, which is an inherent trait of companies because they often operate under financial and human resource constraints limiting their ability to achieve social and economic goals. Improving network relationships is very important for companies in the procurement function to achieve long-term social impacts (Meqdadi et al., 2020). The network can explain to the company to identify the right partner with the relevant capabilities and resources to complement the company's resource needs, coordinate resources for reliable long-term collaboration, and use relational skills to build and maintain important relationships among network partners (Lehtimäki et al., 2018).

Previous studies have shown that networks are an important source of competitive advantage (Drummond et al., 2018; Mitrega et al., 2017; Parida et al., 2017). In addition, the principle also contains a commitment to fair and ethical treatment of other stakeholders with companies that bring greater value to companies on both financial and reputational sides (Starcevic et al., 2018). In this paper, network relationships are defined by three fundamental factors: customer relationships, supply chain relationships, and collaboration.

The relationship between the customer and the company and competitive advantage are considered important tools needed to compete efficiently and effectively (Thongrawd et al., 2020). Paying attention to customer relationships makes organizations more profitable and sustainable in a competitive market if they retain existing customers rather than attract new customers (Sofi et al., 2020). It can be done by meeting the needs of existing customers and maintaining long-standing relationships. One of the tangible results of implementing customer relationships is increasing corporate profits by increasing customer buying behavior in the future (Alqershi et al., 2020). A fully-functional customer relationship can be considered a competitive advantage even for small and medium-sized companies (Pohludka and tverková, 2019).

Furthermore, customer relationships are built on combining people, processes, and technology at various levels of the organization to better understand customer needs with value as a primary concern. Thus, the application of customer relationships is to maximize customer satisfaction and retention to build lasting relationships (Raina, 2017). Companies can focus on customer relationship-based strategies when an economic crisis occurs, which results in a decrease in communication and marketing budgets (Papasolomou et al., 2016). Arsik et al. (2018) and Siu (2016) present a positive relationship between business performance and customer relationship implementation. Their study shows the importance of customer relations in the case of SMEs to instill sustainability into the business in the long term and maintain business performance.

Collaboration can affect business resilience, performance, and business flexibility (Saputra et al., 2020). Collaborative capabilities enable the creation of new opportunities through building and managing relationships between organizations based on mutual trust, communication, and commitment. Collaboration also allows SMEs to adapt quickly 
to changing dynamic economic environments by relying on social interactions that impact innovation (Castilho \& Quandt, 2017). Collaboration allows companies to exchange strategic resources and capabilities. Therefore companies that choose to pursue networking as a strategy should develop capabilities, structures, and processes to support collaborative approaches (Drummond et al., 2018; Mitrega et al., 2017; Parida et al., 2017). Strategic alliances have an important role in supporting the success of industrial development because so far in Indonesia, it is still short-term. They should review the goodwill of business partners, business network consulting, brokerage support, capital accumulation through internal measures, capital accumulation through government support, political support, implementation issues of political support/barriers, an adaptation of business models, and internal restructuring (Kuckertz et al., 2020). SMEs should take a collaborative approach to all company partners, clients, systems, cargo shippers, call centers, unions, competitors, and exchange affiliates (Rapaccini et al., 2020).

A sudden state of change like this impacts all nodes (supply chain members) and edges (ties) in the supply chain simultaneously. As a result, supply chain flows have been substantially disrupted. For example, the demand for necessary items such as personal protective equipment (PPE), ventilators, and dry and canned food has increased. Meanwhile, supply, transportation, and manufacturing face many challenges that reduce their capacity. It includes new rules such as border closures, locks on supply markets, disruption of vehicle movement and international trade, labor shortages, and physical distancing at manufacturing facilities (Amankwah-Amoah, 2020: Gunessee and Subramanian, 2020; Paul and Chowdhury, 2020). Relationships with the supply chain are significant in maintaining business resilience, performance, and sustainability (Ivanov, 2020; Ivanov and Dolgui, 2020). The existence of supply chain relationships can affect business efficiency and performance (Guan et al., 2020; Ivanov, 2020; Sodhi, 2016). The supply chain relationship process must establish a transparent market orientation and learning because knowledge of market orientation and learning is the key to gaining competitive advantage, which ultimately affects the performance of SMEs (Adam et al., 2020). According to prior studies, supply chain-driven change is related to business performance, both economic and non-economic.

\section{Network in Covid-19 context}

The impact of the Covid-19 crisis has become a challenge for companies to build investment in customer relationship management processes and improve sales promotions (Kang and Diao, 2020). Based on this explanation, there is a problem between the impact of the economic crisis and maintaining business performance. So it is necessary to build a better relationship between consumers and companies. The research results by Utomo et al. (2020) show that customer relationship management on SME performance has proven positive and significant for maintaining SME performance. 
Customer relationship management is a concept that aims to create long-term customer loyalty and performance. Customer relationship management is carried out by paying attention and fulfilling what customers want. It can be done by offering membership cards, giving vouchers, serving customers individually, and giving special cards at particular moments. These activities will result in high customer loyalty to SMEs. At least, customers will never think of switching to another SME after being satisfied with the current SME. Long-term relationships can help SMEs to sell their products when they find it difficult to catch new consumers during the pandemic. In addition, loyal customers always remember the provider. They feel less necessary to look for other products or other providers because they still have to bear the risk of being dissatisfied with other alternatives. Long-term relationship-oriented customer relationship management is an advantage for SMEs in maintaining their performance during the COVID-19.

A strategic approach in developing SMEs by involving collaborative roles from various parties to realize SMEs empowerment as one of the handlings of the economy and maintaining business performance during the Covid-19 period. The SME empowerment program is related to various sectors in the business processes carried out, so it requires the role of various stakeholders. The success of the SME development program depends on how the government can collaborate with various stakeholders to realize the progress and sustainability of SMEs in the future. It can be done by establishing cooperation between the Provincial Government, Regency/City Governments, the SMEs community that sells materials in the region, and the SME community. In addition, other research shows that collaboration in the Penta helix between academia, business, government, community, and media is very much needed to achieve policy goals to overcome the impact of Covid-19 on SMEs (Yunus et al., 2020). This first step includes partnerships with all stakeholders and focuses on mutually beneficial outcomes. We must not forget the support system (friends, neighbors, and relatives) during this process and identify their skills and expertise to facilitate collaboration and positive contribution to business continuity.

Some suggested steps as part of this robust approach are SMEs in partnership with other businesses. Local councils (or equivalent) should increase advertising to attract and encourage customers to buy local products. Sectors such as groceries and hospitality are well suited to market themselves and focus on local customers (Zutshi et al., 2021). Paul and Chowdhury (2020) supported this finding, who suggest horizontal collaboration between similar producers at the national level to ensure the supply of products needed during this crisis. Based on a survey conducted by 33 SMEs in the field of handicrafts in the city of Solo. SMEs maintain good relations with partners. A good relationship with partners, among others, with suppliers and distributors. SMEs also feel that cooperation with partners is indispensable for business development. Collaboration with partners can also be used to get new ideas and when businesses need help. Expanding business 
networks is done by joining organizations with SMEs in similar fields (Nugraheni et al., 2020).

The Covid-19 pandemic has disrupted supply chain relationships, particularly for small and medium-sized enterprises (SMEs), whose experiences during the pandemic are expected to worsen than those made during the financial crisis in previous years (Liu and Parilla, 2020). Relationships with supply chains are critical in maintaining business resilience, performance, and sustainability (Ivanov, 2020; Ivanov and Dolgui, 2020). The existence of supply chain relationships can affect business efficiency and performance (Guan et al., 2020; Ivanov, 2020; Sodhi, 2016). The supply chain relationship process must establish a transparent market orientation and learning because knowledge of market orientation and learning is the key to gain competitive advantage, which ultimately affects the performance of SMEs (Adam et al., 2020). The advent of Covid 19 has been a challenge as many SME suppliers provide single-source equipment or services that are not available from other suppliers. This decrease in interaction leads to incomplete information, leading to information ambiguity and a lack of clarity and accuracy (Baveja et al., 2020; Gunessee and Subramanian, 2020). In addition, this has reduced supplier involvement, making it difficult for companies to develop a collaborative approach that integrates all parties involved (van Hoek, 2020). As Gupta et al. (2020) note, opportunistic behavior may also increase, and undisturbed suppliers may charge higher prices if they see that other suppliers have been affected by the disruption.

Some strategies that can be done are to improve supply chain relationships, and collaboration can protect companies from negative impacts, enabling rapid recovery and preparation for future activities (Hobbs, 2020; Paul and Chowdhury, 2020a; Sharma et al., 2020). In addition, maintain relationships with supply chain partners to meet each other's requirements. Knowledge management also needs to be done by sharing important information, ideas, and expertise (Jabbour et al., 2020) and synchronizing strategic processes (Sharma et al., 2020). It can also help in dealing with the impact of Covid-19. Such exchange of information and knowledge can reduce information ambiguity, which is a significant problem for businesses during a pandemic or other major disruption (Gunessee and Subramanian, 2020). The government has recognized this risk and is continuously working to reduce it (which ultimately means recruiting and retaining higher-quality SME suppliers). The smallest suppliers may require closer monitoring and be provided with different types of assistance when navigating crises due to their very limited resources (Melnyk et al., 2020).

Proposition 6a: Network Relationship from Customer Relationship positively improve business performance in the Covid-19 era.

Preposition 6b: Network Relationship from Collaboration positively improve business performance in the Covid-19 era. 
Proposition 6c: Network Relationship from Supply Chain Relationship positively improve business performance in the Covid-19 era.

After all the explanation and the proof of concept from the past research, we tried to bridge the concept and have clear exposure of our idea about transformation drives with the business performance variable. For instance, the transformation drives as independent and business performance as the dependent variable which is presented in Fig. 1.

Figure 1. Conceptual Framework

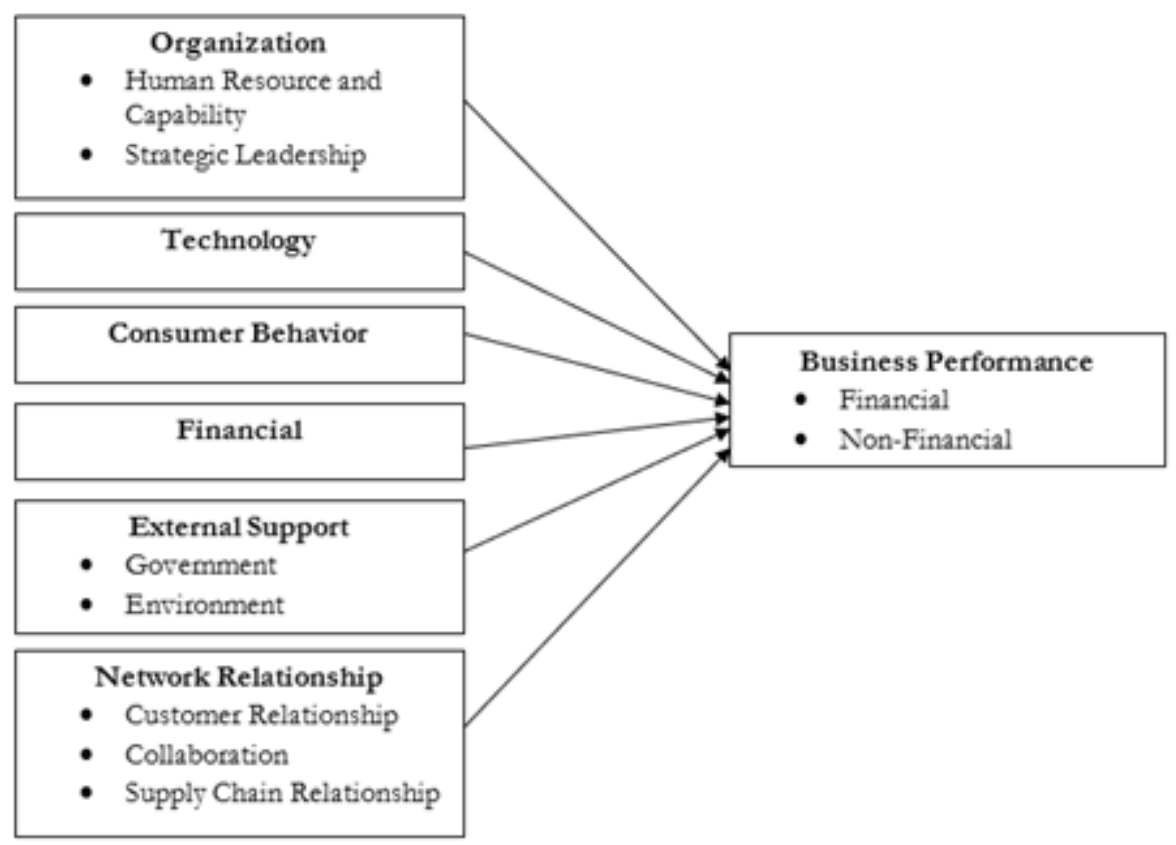

\section{CONCLUSIONS AND SUGGESTIONS}

In this section, we discuss the objective of the paper, the findings, and how it relates to current conditions in startup businesses. Next, we discuss managerial and theoretical implications and contributions and provide future research suggestions to extend this paper. After the transformation drives mentioned above for the impact on business performance in the Covid-19 situation, we try to conclude all of our conceptual paper:

In order to sustain and compete in a crisis environment like the Covid-19 pandemic, a leader's capability takes a role in building a company's capacity through their strategic decision. The quality of employees also plays a role in influencing the success of strategy formulation to be implemented to achieve optimal business performance. Technological improvements and changes during business processes can produce business effectiveness and efficiency, impacting business sustainability and 
performance. Consumer behavior plays an important role in anticipating business performance and achieving its sustainable competitive advantage. Loyal customers have become an element of capital and one of the key success factors in business performance. Business transformation through financial drivers can be seen from businesses re-budgeting their financial structure, which aims to allocate the budget to priorities according to the most important business performance.

Past research has related to business performance from external support the government and environment have proven by past research. The way of support can help the SME to survive in the covid-19 situation. Improving network relationships is very important for companies in the procurement function to achieve long-term social impact. Also, organizations will be more profitable and sustainable in a competitive market if they maintain network relationships.

This study integrates knowledge in SMEs transformation drivers due to Covid-19 from three streams of literature database and found internal and external factors in the organization become factor drivers for SMEs transformation. This study enriches theoretical discussion on SME's transformation drivers and their impact on economic and non-economic performance through conducting literature reviews. This study advances business survival knowledge to face a dynamic environment like the Covid-19 pandemic and strategic innovation related to business performance. Therefore, we provide a foundation of a theoretical building that may motivate the research agenda to continue this topic comprehensively.

This study suggests that seven transformation drivers in SMEs take a role in coping with their business sustainability in the crisis-era of Covid-19. The comprehensive study has created strategic development on how SMEs should focus on transformation drivers and their impact on their business performance. Leader/owner/manager in SMEs can sooner transform their business model by focusing on seven factors we found as the most essential in driving transformation in SMEs. Policymakers can utilize this paper to make policy decisions regarding SMEs and their need for support and stimulus.

\section{REFERENCES}

Adam, M., Ibrahim, M., Ikramuddin, and Syahputra, H. (2020): The role of digital marketing platforms on supply chain management for customer satisfaction and loyalty in small and medium enterprises (SMEs) at Indonesia, International Journal of Supply Chain Management, 9(3), 1210-1220.

Adam, N. A., \& Alarifi, G. (2021). Innovation practices for survival of small and medium enterprises (SMEs) in the COVID-19 times: the role of external support. Journal of Innovation and Entrepreneurship, 10(1). https://doi.org/10.1186/s13731-021-001566 
Alqershi, N., Ismail, A. I., Abualrejal, H., and Salahudin, S. N. (2020): Competitive Advantage Achievement through Customer Relationship Management Dimensions, Journal of Distribution Science, https://doi.org/10.15722/jds.18.11.202011.61

Amankwah-Amoah, J., (2020). Note: Mayday, Mayday, Mayday! Responding to environmental shocks: Insights on global airlines' responses to COVID-19. Transp. Res. Part E Logist. Transp. Rev. 143, 102098. https://doi.org/10.1016/j.tre.2020.102098.

Amuda, Y. J. (2020). Impact of Coronavirus on Small and Medium Enterprises (SMEs): Towards Post-Covid-19 Economic Recovery in Nigeria. Academic of Strategy Management Journal, 19(6), 1-11.

Arsic', S.; Banjevic', K.; Nastasic', A.; Rošulj, D.; Arsic', M. (2018). Family business owner as a central figure in customer relationship management. Sustainability, 11, 77.

Asioli, D., Varela, P., Hersleth, M., Almli, V. L., Olsen, N. V., \& Naes, T. (2017). A discussion of recent methodologies for combining sensory and extrinsic product properties in consumer studies. Food Quality and Preference, 56, pp. 266-273.

Astuti, E. S., Sanawiri, B., \& Iqbal, M. (2020). Attributes of Innovation, Digital Technology and Their Impact on SME Performance in Indonesia. International Journal of Entrepreneurship, 24(1), 1-14. https://doi.org/10.6084/m9.figshare.12228692

Barney, J. B., \& Wright, P. M. (1998). On becoming a strategic partner: The role of human resources in gaining competitive advantage. Human Resource Management, 37(1), $31-46$.

Baryshnikova, N., Kiriliuk, O., \& Klimecka-tatar, D. (2021). Enterprises' strategies transformation in the real sector of the economy in the context of the COVID-19 pandemic. Production Engineering Archives, 27(1), 8-15. https://doi.org/10.30657/pea.2021.27.2

Baveja, A., Kapoor, A., Melamed, B., (2020). Stopping Covid-19: a pandemicmanagement service value chain approach. Ann. Oper. Res. 289, 173-184. https://doi.org/ 10.1007/s10479-020-03635-3.

Benhayoun, L., Le-Dain, M. A., \& Dominguez-Péry, C. (2021). Characterising absorptive capacity supporting smes' learnings within collaborative innovation networks: Insights from multi-level case studies. International Journal of Innovation Management, 25(4). https://doi.org/10.1142/S136391962150047X

Botti, S. and McGill A., L. (2011), The Locus of Choice:Personal Causality and Satisfaction with Hedonic and Utilitarian Decisions, Journal of Consumer Research, 37 (6), pp. 1065-1078.

BPS. (2020). Analisis Hasil Survei Dampak COVID-19 terhadap Pelaku usaha. ISSN / ISBN 978-602-438-350-3. 
Buchdadi, A. D., Sholeha, A., Ahmad, G. N., \& Muskon. (2020). The Influence of Financial Literacy on SMEs Performance Through Access to Finance and Financial Risk Attitude as Mediation Variables. Academy of Accounting and Financial Studies Journal, 24(5), 1-16.

Caballero-Morales, S. O. (2021). Innovation as recovery strategy for SMEs in emerging economies during the COVID-19 pandemic. Research in International Business and Finance, 57. https://doi.org/10.1016/j.ribaf.2021.101396

Castilho, M. F., \& Quandt, C. O. (2017). Collaborative capability in coworking spaces: convenience sharing or community building?, Technology Innovation Management Review, 7(12).

Depkop. (2018). Perkembangan Data Usaha Mikro, Kecil , Menengah Dan Usaha Besar. In Www.Depkop.Go.Id (Issue 1).

Dong, B., Xu, H., Luo, J., Nicol, C. D., and Liu, W. (2020): Many roads lead to Rome: How entrepreneurial orientation and trust boost the positive network range and entrepreneurial performance relationship, Industrial Marketing Management, 88(February), 173-185. https://doi.org/10.1016/j.indmarman.2020.04.016

Donthu N, Gustafsson A, (2020). Effects of COVID-19 on business and research J. Bus. Res. 117, 284-289.

Drummond, C., McGrath, H. and O'Toole, T. (2018) 'The impact of social media on resource mobilisation in entrepreneurial firms', Industrial Marketing Management, Vol. 70, pp.68-89. https://doi.org/10.1016/j.indmarman.2017.05.009.

Falahat, M., Lee, Y. Y., Soto-Acosta, P., \& Ramayah, T. (2021). Entrepreneurial, market, learning and networking orientations as determinants of business capability and international performance: the contingent role of government support. International Entrepreneurship and Management Journal, 0123456789. https://doi.org/10.1007/s11365-020-00738-y

Fath, B., Fiedler, A., Sinkovics, N., Sinkovics, R. R., \& Sullivan-taylor, B. (2021). International Relationship and Resilience of New Zealand SME exporters During Covid-19. Critical Perspective on International Business, 17(2), 359-379.

García-villagrán, A., Cano-olivos, P., Martínez-flores, J. L., \& Sánchez-partida, D. (2020). The COVID-19 Effect in Mexican SMEs. Advances in Science, Technology and Engineering Systems Journal, 5(6), 63-71.

Gonda, G., Gorgenyi-Hegyes, E., Nathan, R. J., and Fekete-Farkas, M. (2020): Competitive Factors of Fashion Retail Sector with Special Focus on SMEs, Economies, 8(4), 95. https://doi.org/10.3390/economies8040095

Gregurec, I., Tomičić Furjan, M., \& Tomičić-pupek, K. (2021). The impact of covid-19 on sustainable business models in SMEs. Sustainability (Switzerland), 13(3), 1-24. 
Guan, D., Wang, D., Hallegatte, S., Davis, S.J., Huo, J., Li, S., Bai, Y., Lei, T., Xue, Q., Coffman, D.M., Cheng, D., Chen, P., Liang, X., Xu, B., Lu, X., Wang, S., Hubacek, K., Gong, P., (2020). Global supply-chain effects of COVID-19 control measures. Nat. Hum. Behav. 4, 577-587. https://doi.org/10.1038/s41562-020-0896-8.

Gunessee, S., Subramanian, N., (2020). Ambiguity and its coping mechanisms in supply chains lessons from the Covid-19 pandemic and natural disasters. Int. J. Oper. Prod. Manag. ahead-of-print 1-23. https://doi.org/10.1108/IJOPM-07-2019-0530.

Guo, H., Yang, Z., Huang, R., \& Guo, A. (2020). The digitalization and public crisis responses of small and medium enterprises : Implications from a COVID-19 survey. Frontiers of Business Research in China, 14(19), 1-25.

Gupta, V., Ivanov, D., Choi, T.M., (2020). Competitive pricing of substitute products under supply disruption. Omega ahead-of-print. https://doi.org/10.1016/j. Omega.2020.102279.

Hall M C, Prayag G, Fieger P, Dyason D 2020 Beyond panic buying: consumption displacement and COVID-19 J. Serv. Manag. 2020

Harahap, D. A., Putra, A., Teviana, T., and Amanah, D. (2020): What Is The Reason For Consumer Buying At Indonesia SMEs Market- Palarch's, Journal Of Archaeology Of Egypt/Egyptology, 17(4), 507-524.

Hendayana, Y., Suryana, Disman, M.S., Mulyadi, H., Saputra, J. (2019). The empowering comparative supply chain operations of batik SMEs through uniqueness of packaging, productivity and innovation. International Journal of Supply Chain Management, Volume 8, Issue 5, Pages 986-993.

Hendrawaty, E., Widiyanti, M., \& Sadalia, I. (2020). C.E.O Financial Literacy and Corporate Financial Performance in Indonesia: Mediating Role of Source of Investment Decisions. Journal of Security and Sustainability Issues, 9.

Hennig-thurau, T., Malthouse, E. C., Friege, C., Gensler, S., Lobschat, L., Rangaswamy, A., \&Skiera, B. (2010). The Impact of New Media on Customer Relationships. Journal of Service Research, 13(3), 311-330.

Hennig-thurau, T., Malthouse, E. C., Friege, C., Gensler, S., Lobschat, L., Rangaswamy, A., \&Skiera, B. (2010). The Impact of New Media on Customer Relationships. Journal of Service Research, 13(3), 311-330.

Hindasah, L., \& Nuryakin, N. (2020). The Relationship between Organizational Capability , Organizational Learning and Financial Performance. Journal of Asian Finance, Economics and Business, 7(8), 625-633. https://doi.org/10.13106/jafeb.2020.vol7.no8.625

Hobbs, J.E., (2020). Food supply chains during the COVID-19 pandemic. Can. J. Agric. Econ. 68, 171-176. https://doi.org/10.1111/cjag.12237. 
Hosmer, L. T. (1986). The Importance of Strategic Leadership. Journal of Business Strategy, 3, 47.

Huang, S.-P. (2014). A Study on the Relations among the Human Resource Management System, Organizational Commitment and Business Performance. Acta Oecomonica, 64(S2), 275-288. https://doi.org/10.1556/AOecon.64.2014.Suppl.19

Hutabarat, C., Suharyono, S., Utami, H. N., \& Prasetya, A. (2021). Servant Leadership , Business Transformation, and Corporate Competitiveness. Journal of Asian Finance, Economics and Business, 8(2), 1091-1099. https://doi.org/10.13106/jafeb.2021.vol8.no2.1091

Ibarra, D., Bigdeli, A. Z., Igartua, J. I., \& Ganzarain, J. (2020). Business Model Innovation in Established SMEs: A Configurational Approach. Journal of Open Innovation: Technology, Market, and Complexity, 6(76), 1-22.

Ivanov, D., 2020. Predicting the impacts of epidemic outbreaks on global supply chains: a simulation-based analysis on the coronavirus outbreak (COVID-19/SARS-CoV-2) case. Transp. Res. Part E Logist. Transp. Rev. 136, 101922 https://doi.org/10.1016/j.tre.2020.101922.

Ivanov, D., Dolgui, A., (2020). OR-methods for coping with the ripple effect in supply chains during COVID-19 pandemic: managerial insights and research implications. Int. J. Prod. Econ. ahead-of-print 107921. https://doi.org/10.1016/j.ijpe.2020.107921.

Jabbour A B L S, Jabbour C J C, Hingley M, Vilalta-Perdomo E L, Ramsden G, Twigg D 2020. Sustainability of supply chains in the wake of the coronavirus (COVID19/SARS-CoV-2) pandemic: lessons and trends Mod. Supply Chain Res. Appl. 23 117-122.

Jabbour, A.B.L. de S., Jabbour, C.J.C., Hingley, M., Vilalta-Perdomo, E.L., Ramsden, G., Twigg, D., (2020). Sustainability of supply chains in the wake of the coronavirus (COVID-19/SARS-CoV-2) pandemic: lessons and trends. Mod. Supply Chain Res. Appl. https://doi.org/10.1108/mscra-05-2020-0011

Jiménez-zarco, A. I., Clemente-almendros, J. A., González-gonzález, I., \& Aracil-jordà, J. (2021). Female Micro-Entrepreneurs and Social Networks : Diagnostic Analysis of the Influence of Social-Media Marketing Strategies on Brand Financial Performance. Frontiers in Psychology, 12. https://doi.org/10.3389/fpsyg.2021.630058

Jing, F. F., Avery, G. C., \& Bergsteiner, H. (2020). Leadership Variables and Business Performance: Mediating and Interaction Effects. Journal of Leadership \& Organizational Studies, 27(1), 80-97. https://doi.org/10.1177/1548051818824532

Juntarbutra, S., Kuntornbutre, C., \& Na-nan, K. (2020). The Influence of Transformational Leadership, Business Strategy, and Organization Innovation on Business Performance in the Thai Automotive Parts Industry. Academy of Strategic Management Journal, 19(3), 2-13. 
Kang, J., \& Diao, Z. (2020). Business-to-business marketing responses to COVID-19 crisis: a business process perspective. Marketing Intelligence \& Planning. doi:https://doi.org/10.1108/MIP-05- 2020-0217.

Kemenkes. (2021). Covid-19. https://infeksiemerging.kemkes.go.id/dashboard/covid-19

Khan, A., \& Lodhi, S. (2016). Influence of Celebrity Endorsement of Consumer Purchase Decision: A Case of Karachi. Journal of Interdisciplinary Research, 2(1), 102-111.

Klein, V. B., \& Todesco, J. L. (2021). COVID-19 crisis and SMEs responses: The role of digital transformation. Knowl Process Manag., 28, 117-133. https://doi.org/10.1002/kpm.1660

Kuckertz A, Brändle L, Gaudig A, Hinderer S, Reyes C A M, Prochotta A, Steinbrink K M, Berger E S C. (2020). Startups in times of crisis - A rapid response to the COVID19 pandemic, J. Bus. Ventur. Insights 13 e00169

Kumar M S, Maheshwari V, Prabhu J, Prasanna M, Jayalakshmi P, Suganya P, Benjula Anbu Malar M B, Jothikumar R 2020 Social economic impact of COVID-19 outbreak in India Int. J. Pervasive Comput. Commun. 164 309-19

Kuntonbutr, C., Jaturus, N., \& Kulken, M. (2020). The Effects of Organisational Support on SMEs' Perceived Performance: The Role of Human Resource Development, Innovation, and Information Technology. International Journal of Innovation, Creativity and Change, 13(6), 1299-1314.

Lehtimäki, T., Komulainen, H., Oinonen, M. and Salo, J. (2018) 'The value of long-term co-innovation relationships: experiential approach', International Journal of Business Innovation and Research, Vol. 16, No. 1, p.1 https://doi.org/10.1504/ IJBIR.2018.091078.

Liu, S., Parilla, J., (2020). What the great recession can tell us about the COVID-19 small business crisis. The Brookings Institute. July 18, 2021. https://www.brookings. edu/blog/the-avenue/2020/03/25/what-the-great-recession-can-tell-us-about-thecovid-19-small-business-crisis/.

Melnyk, S. A., Schoenherr, T., Verter, V., Evans, C., and Shanley, C. (2021): The pandemic and SME supply chains: Learning from early experiences of SME suppliers in the U.S. defense industry, Journal of Purchasing and Supply Management, In Press. https://doi.org/10.1016/j.pursup.2021.100714

Meqdadi, O., Johnsen, T. E., and Pagell, M. (2020): Relationship configurations for procuring from social enterprises, International Journal of Operations and Production Management, 40(6), 819-845. https://doi.org/10.1108/IJOPM-07-20190523

Mitrega, M., Forkmann, S., Zaefarian, G. and Henneberg, S.C. (2017) Networking capability in supplier relationships and its impact on product innovation and firm 
performance, International Journal of Operations \& Production Management, Vol. 37, No. 5, pp.577-606. https://doi.org/10.1108/IJOPM-11-2014-0517.

Moretto, A., \& Caniato, F. (2021). Can Supply Chain Finance help mitigate the financial disruption brought by. Journal of Purchasing and Supply Management. https://doi.org/10.1016/j.pursup.2021.100713

Mui, H. K. Y., Basit, A., \& Hassan, Z. (2018). The Impact of Strategic Leadership on Organizational Performance of Small Medium Enterprises ( SME) in Malaysia. Journal of Leadership and Management, 13, 154-166.

Muñoz-pascual, L. (2021). Contributions to Sustainability in SMEs: Human Resources , Sustainable Product Innovation Performance and the Mediating Role of Employee Creativity. Sustainability, 13(4), 1-20. https://doi.org/10.3390/su13042008.

Nohong, M., Munir, A. R., \& Hakim, H. (2021). Financing Decision, Human Capital Investment, and Entrepreneurial Performance: An Empirical Study on SME in Makassar. Academy of Strategic Management Journal, 20(3), 1-12.

Nugraheni, Agustina Prativi, D. (2020): Strategy of SMEs In The Covid-19 Pandemic Period, Jurnal Akuntansi \& Perpajakan Jayakarta, 2(1), 45-52.

Nurunnabi, M. (2020). Recovery planning and resilience of SMEs during the COVID-19: experience from Saudi Arabia. Journal of Accounting \& Organizational Change. https://doi.org/10.1108/JAOC-07-2020-0095

Nuseir, M. T., \& Aljumah, A. (2020). The Role of Digital Marketing in Business Performance with the Moderating Effect of Environment Factors among SMEs of UAE. International Journal of Innovation, Creativity and Change, 11(3), 310-324.

Oktora, K., Lolita, S. P., Ismail, V. Y., Novesar, M. R., \& Bon, A. T. (2020). E-commerce adoption level in smes since pandemic covid-19 case in bogor, indonesia. Proceedings of the International Conference on Industrial Engineering and Operations Management, 59, 1836-1847.

Organisation for Economic Co-operation and Development OECD, (2020a), COVID-19 and the Food and Agriculture Sector: Issues and Policy Responses, (online), available at http://www.oecd.org/coronavirus/en.

Papasolomou, I., Kitchen, P. J., Panopoulos, A., \& Sabova, M. (2016). Economic Crisis and its Impact on Promotion and Media in Cyprus. Journal Of Promotion Management, 22(5), 719-734. doi:https://doi.org/10.1080/10496491.2016.1185495

Parida, V., Pesämaa, O., Wincent, J. and Westerberg, M. (2017) Network capability, innovativeness, and performance: a multidimensional extension for entrepreneurship, Entrepreneurship and Regional Development, Vol. 29, Nos. 1-2, pp.94-115.https://doi.org/10.1080/08985626.2016.1255434.

Patma, T. S., Wardana, L. W., Wibowo, A., \& Narmaditya, B. S. (2020). The Shifting of Business Activities during the COVID-19 Pandemic: Does Social Media Marketing 
Matter?, Journal of Asian Finance, Economics and Business, 7(12), 283-292. https://doi.org/10.13106/jafeb.2020.vol7.no12.283

Paudel, S. (2018). Entrepreneurial leadership and business performance: Effect of organizational innovation and. South Asian Journal of Business Studies, 8(3), 348369. https://doi.org/10.1108/SAJBS-11-2018-0136

Paul, S.K., Chowdhury, P., (2020a). A production recovery plan in manufacturing supply chains for a high-demand item during COVID-19. Int. J. Phys. Distrib. Logist. Manag.,1-22. https://doi.org/10.1108/IJPDLM-04-2020-0127.

Paul, S.K., Chowdhury, P., (2020b). Strategies for managing the impacts of disruptions during COVID-19: an example of toilet paper. Glob. J. Flex. Syst. Manag. 21, 283293. https://doi.org/10.1007/s40171-020-00248-4.

Pham, D. H. (2020). Impact of human resource management practices on enterprises competitive advantages and business performance: Evidence from telecommunication industry. Management Science Letters, 10, 721-732. https://doi.org/10.5267/j.msl.2019.10.025

Pohludka, M.; Štverková, H. (2019). The Best Practice of CRM Implementation for Smalland Medium-Sized Enterprises. Adm. Sci., 9, 22.

Pratama, V., Santoso, I., \& Mustaniroh, S. A. (2021). Development strategy of SMEs in the new normal era of coronavirus disease 2019 (COVID-19): A literature review. IOP Conference Series: Earth and Environmental Science, 733(1), 012058. https://doi.org/10.1088/1755-1315/733/1/012058

Prima Lita, R., Fitriana Faisal, R., \& Meuthia, M. (2020). Enhancing small and medium enterprises performance through innovation in Indonesia: A framework for creative industries supporting tourism. Journal of Hospitality and Tourism Technology, 11(1), 155-176. https://doi.org/10.1108/JHTT-11-2017-0124

Purwati, A. A., Budiyanto, Suhermin, \& Hamzah, M. L. (2021). The effect of innovation capability on business performance: The role of social capital and entrepreneurial leadership on SMEs in Indonesia. Accounting, 7, 323-330. https://doi.org/10.5267/j.ac.2020.11.021

Rachmawati, R., \& Widowati. (2021). Research of the Impact of Financial Dimensions and Entrepreneurial Capacity on Business Performance in Small and Medium Enterprises in Central Java. Universal Journal of Accounting and Finance, 9(1), 122-129. https://doi.org/10.13189/ujaf.2021.090113

Rachmawati, R., \& Widowati. (2021). Research of the impact of financial dimensions and entrepreneurial capacity on business performance in small and medium enterprises in Central Java. Universal Journal of Accounting and Finance, 9(1), 122-129. https://doi.org/10.13189/ujaf.2021.090113 
Radicic, D. (2020). National and international R\&D support programmes and technology scouting in European small and medium enterprises. Journal of Science and Technology Policy Management, 11(4), 455-482. https://doi.org/10.1108/JSTPM10-2019-0091

Raina, D. I. (2017). Impact of Customer relationship Management n customer Satisfaction and Loyalty: a study of Telecom companies in J\&K. Researchers World, 8(4), 115123. DOI:10.18843/rwjasc/v8i4/14

Rajagopal, D., (2020). Development of Consumer Behavior. In Transgenerational Marketing, Springer International Publishing, pp. 163-194.

Rapaccini M, Saccani N, Kowalkowski C, Paiola M, Adrodegari F. (2020). Navigating disruptive crises through service-led growth: The impact of COVID-19 on Italian manufacturing firms. Ind. Mark. Manag. 88 225-37

Rita, M., \& Huruta, A. D. (2020). Financing Access Performance: A Case Study from Batik SME in Indonesia. International Journal of Innovation, Creativity and Change, 12(12), 203-224.

Rodrigues, M., Franco, M., Sousa, N., \& Silva, R. (2021). COVID 19 and the Business Management Crisis : An Empirical Study in SMEs. Sustainability, 13, 1-20.

Rosli, M. M., \& Sidek, S. (2013). The Impact of Innovation on the Performance of Small and Medium Manufacturing Enterprises: Evidence from Malaysia. Journal of Innovation Management in Small \& Medium Enterprise, 1-16. https://doi.org/10.5171/2013.885666

Salamzadeh, A., \& Dana, L. P. (2020). The coronavirus ( COVID-19) pandemic: challenges among Iranian startups. Journal of Small Business \& Entrepreneurship, 1-24. https://doi.org/10.1080/08276331.2020.1821158

Sanusi, Suheny, E., Arum, M., Wandi, D., Rahmat, A., Kurnianingsih, A., Haerani, A., Dasmaran, V., Taryanto, Adha, S., \& Purwanto, A. (2020). Develop Leadership Style Model for Indonesian SMEs Leaders During Covid-19 Pandemic. Systematic Reviews in Pharmacy, 11(8), 576-586.

Saputra, N., Prihandoko, D., and Hidayat, B. (2020): Collaborative Capability : Memperkuat Ketahanan UMKM Melewati Krisis Covid-19, Seminar Nasional Manajemen Dan Call for Paper (SENIMA 5), 1-8.

Sharma, A., Adhikary, A., Borah, S.B., (2020). Covid-19' s impact on supply chain decisions: strategic insights from NASDAQ 100 firms using Twitter data. J. Bus. Res. 117, 443-449. https://doi.org/10.1016/j.jbusres.2020.05.035.

Siu, N. (2016). Customer Relationship Management and Recent Developments. Adm. Sci., $3,7$. 
Sodhi, M.S., (2016). Natural disasters, the economy and population vulnerability as a vicious cycle with exogenous hazards. J. Oper. Manag. 45, 101-113. https://doi. org/10.1016/j.jom.2016.05.010.

Sofi, M. R., Bashir, I., Parry, M. A., \& Dar, A. (2020). The effect of customer relationship management (CRM) dimensions on hotel customer's satisfaction in Kashmir. International Journal of Tourism Cities. DOI 10.1108/IJTC-06-2019-0075

Stanciu, S., Radu, R.-I., Sapira, V., Bratoveanu, B.-D., and Florea, A.-M. (2020): Consumer Behavior in Crisis Situations. Research on the Effects of COVID-19 in Romania, Annals of Dunarea de Jos University of Galati. Fascicle I. Economics and Applied Informatics, 26(1), 5-13. https://doi.org/10.35219/eai1584040975

Starcevic, V.; Billieux, J.; Schimmenti, A. (2018). Selfitis and behavioural addiction: A plea for terminological and conceptual rigour. Aust. New Z. J. Psychiatry, 52, 919-920.

Strukan, E., Nikolić, M., \& Sefić, S. (2017). Impact of Transformational Leadership on Business Performance. 2, 435-444.

Sukartini, N. W., Sudarimini, N. M., \& Lasmini, N. K. (2018). Relationship between human resource ability and market access capacity on business performance (case study of wood craft micro- and small-scale industries in Gianyar Regency, Bali). Journal of Physics: Conference Series 953012084.

Sun, Y., Zeng, X., Zhao, H., Simkins, B., \& Cui, X. (2021). The impact of COVID-19 on SMEs in China : Textual analysis and empirical evidence. Finance Research Letters. https://doi.org/10.1016/j.frl.2021.102211

Thongrawd, C., Ramanust, S., Narakorn, P., \& Seesupan, T. (2020). Exploring the Mediating Role of Supply Chain Flexibility and Supply Chain Agility between Supplier Partnership, Customer Relationship Management and Competitive Advantage. Int. J Sup. Chain. Mgt Vol, 9(2), 435.

Utomo, M. N., Ariska, I., Pratiwi, S. R., and Kaujan, K. (2021): Strategies for Maintaining SMEs Performance During Covid-19 Pandemic, International Journal of Social Science and Business, 5(1), 34-43.

Vaitoonkiat, E., \& Charoensukmongkol, P. (2020). Interaction effect of entrepreneurial orientation and stakeholder orientation on the business performance of firms in the steel fabrication industry in Thailand. Journal of Entrepreneurship in Emerging Economies, 12(4), 453-473. https://doi.org/10.1108/JEEE-05-2019-0072

van Hoek, R., (2020). Research opportunities for a more resilient post-COVID-19 supply chain - closing the gap between research findings and industry practice. Int. J. Oper. Prod. Manag. 40, 341-355. https://doi.org/10.1108/lJOPM-03-2020-0165.

Vig, S., \& Agarwal, R. N. (2021). Repercussions of COVID-19 on small restaurant entrepreneurs: The Indian context. Startegic Change, 30(145), 145-152. https://doi.org/10.1002/jsc.2398 
Viswanathan, R., \& Telukdarie, A. (2021). A systems dynamics approach to SME digitalization A systems dynamics approach to SME digitalization. Procedia Computer Science, 180, 816-824. https://doi.org/10.1016/j.procs.2021.01.331

Wahyono, \& Hutahayan, B. (2021). The relationships between market orientation , learning orientation, fi nancial literacy, on the knowledge competence, innovation , and performance of small and medium textile industries in Java and Bali. Asia Pacific Management Review, 26(1), 39-46. https://doi.org/10.1016/j.apmrv.2020.07.001

Wahyudi I 2014 Default risk analysis in micro, small and medium enterprises: Does debt overhang theory occur?, Asian Academy of Management Journal of Accounting and Finance. $10195-131$

Wang, D., Wang, Y., Yang, J., \& Huang, Z. (2021). Managerial Cognitive Bias , Business Transformation, and Firm Performance : Evidence From China. Sage Open, 1-20. https://doi.org/10.1177/2158244021999156

Wardaya, A., So, I. G., \& Bandur, A. (2019). Mediating Effects of Digital Marketing on Dynamic Capability and Firm Performance : Evidence from Small and Medium-sized Enterprises (SMEs) in Indonesia. International Journal of Recent Technology and Engineering, 8(1C2), 461-464.

WHO. (2021). Coronavirus disease (COVID-19) pandemic. https://www.who.int/

Winarsih, Indriastuti, M., \& Fuad, K. (2021). Impact of Covid-19 on Digital Transformation and Sustainability in Small and Medium Enterprises (SMEs): A Conceptual Framework BT - Complex, Intelligent and Software Intensive Systems (L. Barolli, A. Poniszewska-Maranda, \& T. Enokido (eds.); pp. 471-476. Springer International Publishing.

Yunus, H., Farida, N., Astuti, R., Wijayanto, A., Kismartini, K., and Rakasiwi, G. (2021): Collaboration Strengthening among Micro, Small and Medium Enterprises (MSME) in Central Java during Covid-19. Proceedings of the 5th International Conference on Indonesian Social and Political Enquiries (ICISPE), https://doi.org/10.4108/eai.9-10-2020.2304786

Zuraida, U., Gustomo, A., Bekti, R., \& Pangestu, A. B. (2017). The Impact of Human Resource Practices, Employee Quality and Innovation on Performance: An Analysis of Woven Fabric SMEs. International Journal of Applied Business and Economic Research, 15(20), 283-291.

Zutshi, A., Mendy, J., Sharma, G. D., Thomas, A., and Sarker, T. (2021): From Challenges to Creativity: Enhancing SMEs' Resilience in the Context of COVID-19, Sustainability, 13(12), 6542. https://doi.org/10.3390/su13126542 